\title{
Property issues and warranties in share purchase agreements
}

Recerved 21 March 2005

\section{Trevor Maxim}

is a partner in DMH Stallard, specialising in complex commercial conveyancing, business disposals and acquisitions. He has over 20 years' experience in commercial conveyancing transactions, including those of a novel and complex nature.

\section{Abstract}

This paper examines the property aspects in complex purchase agreements, including property warranties, title investigation and potential past and future liabilities and indemnities. It examines the matters to be considered in negotiations and share purchase agreements, considered from a buyer's perspective, which can apply to retail and leisure properties.

\section{Keywords:}

share purchase agreements, past indemnities, pending rent reviews, pending lease renewals, dilapidations, breaches of covenant

\section{GENERAL}

It is vital not to minimise the property aspect in complex share purchase agreements. As property issues tend to be regarded as specialised it is normal for those aspects of the transaction to be dealt with by a specialised team. But as that team is not actively involved in the main negotiations of the share purchase agreement there is a tendency for that team to be isolated from those negotiations. As a result, some aspects of property which should form part of the main negotiations tend to be overlooked and reliance placed on the property warranties which commonly form part of the share purchase agreement.

\section{MATTERS TO BE CONSIDERED AS PART OF THE INITIAL NEGOTIATIONS}

\section{Potential liability for past indemnities}

It is likely that the company will have disposed of leasehold property. As a condition of obtaining the landlord's consent for the assignment of the lease, a covenant will have been given whereby the company will be liable for any future breach of covenant by the purchaser of that property.

The buyer will, of course, receive no benefit from the past disposal of those properties, but the company after purchase will remain liable for any future claim on those covenants. It is next to impossible to quantify the extent of this liability. How this potential 
Outstanding rent reviews

\section{Lease renewals not finalised}

\section{Liability for dilapidations}

liability is dealt with should form part of the initial negotiations. It may be that the purchaser will want to include in the share purchase agreement some residual indemnity for any future potential liability.

\section{Pending rent reviews}

Under the terms of the majority of leases, where the rent is not ascertained at the date of review, there is provision for the rent increase to be 'backdated' and for interest to be paid on this backdated rent. Therefore as part of the 'due diligence' exercise a review of all the leasehold properties should be undertaken, and specific enquiry made of the seller as to whether any pending rent reviews are outstanding and what their current position is.

The liability for 'back rent' can then form part of the negotiations. If it is possible to calculate the likely liability then some allowance can be made for it in calculating the price. If this is not possible then the share purchase agreement could make provision for the seller to refund, when the liability is ascertained, the full extent of the increased rent prior to the date of the purchase of the company.

It is also recommended that a warranty is given to the effect that there are no pending rent reviews (except as disclosed in the disclosure letter). This warranty could provide for the repayment of any 'back rent' on any non-disclosed rent review.

\section{Pending lease renewals}

As part of the due diligence exercise, specific enquiries should be made regarding any leases which are in the process of renewal under the Landlord and Tenant Act of 1954. Such enquiries are important to ensure that the necessary steps have been taken to protect the right of renewal under the Landlord and Tenant Act. Where such renewals are current there may be pending court proceedings requiring actions to be taken by certain dates.

It is also possible that terms may have already been agreed, but not yet formally documented, as to the terms of renewal - such as rent, term of lease etc - which will be binding on the company. It is likely that the increased rent on renewal will be backdated.

This is a similar position to that set out above in connection with a pending rent review, and again the buyer will want to make similar provisions as set out above.

\section{Dilapidations}

If the buyer intends to carry out detailed surveys of the properties, then to some extent the potential liability under the leases for repairs can be ascertained.

The standard of repair under leases will vary from lease to lease. Prior to carrying out the inspection or survey, if possible the surveyor should be made aware of the standard of repair required to be carried out under the terms of the lease. 


\section{Breaches of tenant's covenants}

\section{Liability for service charge}

It should not be overlooked, however, that the majority of leases include requirements for redecoration at set intervals. This obligation requires the tenant to carry out those works on the dates and in the manner stated in the lease. It is possible, therefore, that the surveyor's inspection and report may advise that the property is in a proper state of repair, and yet there is a requirement to redecorate in any event. This could result in a substantial cost to the buyer, which again ought to be considered as part of the negotiations.

It is also important as part of the 'due diligence' exercise to make specific enquiry as to whether there are any outstanding notices of disrepair served by any landlord. If there are then this, again, will involve cost to the buyer and will have to be carried out in accordance with the terms of the lease within the period permitted by the lease. This could be much earlier than the buyer had anticipated that the works needed to be carried out.

It certainly would be appropriate that a warranty be obtained from the seller that there are no pending notices of disrepair except as disclosed in the disclosure letter.

\section{Other breaches of covenant}

As part of the due diligence process it is important for specific enquiry to be made that there are no outstanding notices (whether formal or informal) of any breaches of any of the covenants of the leases.

In addition to dilapidations (dealt with above), common breaches of covenant are unlawful alterations and breach of the permitted use under the terms of the lease. Such covenants will, of course, impose a liability on the company and more importantly put the lease at risk of forfeiture. It is common for share purchase agreements to include a general warranty as to such matters. Nevertheless, it is better to be aware of them rather than rely on the warranties.

\section{Service charge liability}

Where leases contain provision for the payment of a service charge there is a potential for pending liability. The majority of service charge provisions contain an obligation to make payments on account. At the end of the service charge financial year, a final account is taken and the tenant can be called upon to pay a balancing charge.

It is possible that this balancing charge will not be demanded until some time after the purchase has been completed. The payment will, of course, fall upon the company. It may be possible to get some idea of the likely level of contributions from past service charge accounts.

In any event as part of the due diligence process specific enquiry should be made if the seller has received any indication of major expenditure which could result in a substantial balancing charge 


\section{Compliance with statutory obligations}

\section{Property issues due} diligence payment. Again, a warranty might be sought to the effect that there will be no service charge balancing charges in excess of a stated amount. If demands are received in excess of this amount then the excess would be payable by the seller.

\section{Statutory compliance}

It is common practice to obtain a general warranty from the seller that all relevant statutory provisions have been complied with. Nevertheless, due consideration should be given to the following matters upon which specific enquiry should be considered.

- Inspection by statutory authorities. Depending upon the nature of the business conducted statutory bodies carry out regular inspections. It would be useful to ascertain the dates of these inspections and whether any matters were revealed, even if this is by way of an informal notice.

- What steps have been taken to comply with the provisions of the Disability Discrimination Act of 1995 ?

- Compliance with Regulation 4 of the Control of Asbestos at Work Regulations 2002.

\section{DUE DILIGENCE PROCESS}

\section{Extent of due diligence process}

A proper due diligence process in relation to property can be an expensive and time-consuming process. This is particularly true when a large number of properties are involved. It is often tempting to cut down on this process in order to save costs and rely on the general property warranties which normally form part of the share purchase agreement.

As can be seen from the examples above, there are matters which ought to be specifically considered as part of the due diligence process.

\section{Investigation of title and perusal of leases}

Frequently a 'package' of documents will be made available for inspection by potential purchasers prior to an offer being made. As set out above, it is tempting to cut down on this process in view of the substantial cost involved in a detailed and proper inspection of the package, particularly where this is to take place prior to an offer being made.

The difficulty in adopting this high-risk strategy is that in the disclosure letter given by the seller, reference will usually be made to the 'package' of documents, the effect of which is that the seller escapes liability under the warranties for any matters that would be disclosed by inspection of the package of documents.

In view of this risk it is vital that a proper due diligence process 


\section{Standards of due diligence}

\section{Property team and negotiations}

be undertaken by a detailed inspection of the package of documents. This inspection should be carried out by a competent team of property lawyers experienced in such matters.

It is important that specific instructions are issued to the property lawyers setting out clearly the extent of those enquiries and requiring a detailed report to be prepared following that inspection. If the terms of the instructions to the property lawyers are clear and unambiguous then they will deal with any items of concern and address the issues highlighted above.

\section{Requirements for due diligence exercise by the property team}

Wherever possible the property team should seek to obtain the following from the sellers.

- A certificate of title in the form of the City of London Law Society Land Law Sub-Committee Long Form Certificate of Title. This is an extremely detailed certificate, and will need to be adapted to take into account the nature of the transaction.

- Local searches - these should form part of the certificate of title mentioned above.

- Replies to enquiries, which should ideally be in the form of commercial property standard enquiries prepared by a member of the London Property Support Lawyers Group - again, these should form part of the certificate of title mentioned above.

- Confirmation on the matters set out above to be considered as part of the initial negotiations.

In the event that the seller is not prepared to supply all or any of these documents then the buyer will have to decide as part of the specific instructions issued to the property team the extent to which that team is to obtain the information themselves. This will be by way of inspection of the documents, direct enquiry of the seller's lawyers and, if required, carrying out their own searches and enquiries.

\section{INVOLVEMENT OF PROPERTY TEAM IN NEGOTIATING SHARE PURCHASE AGREEMENT}

As can be seen above there are specific property matters which need to form part of the initial negotiations and to be incorporated in the share purchase agreement. For this reason it is vital that the property team forms an active part in agreeing the share purchase agreement and the warranties and provisions that need to be incorporated in it.

Wherever possible these property issues should be dealt with in the early stages of the negotiations. They are not matters which can easily be dealt with at the last minute when the terms of the agreement are being finalised. 
Warranties: What are their value?

\section{Warranties: What are their extent?}

\section{WARRANTIES: THEIR VALUE EXTENT AND EFFECT}

\section{Value of warranties}

Perhaps the first and most obvious question to be asked is what value the warranties have. As can be seen above, they should be extensive and cover specific as well as general matters. Some of the warranties will carry with them a future financial burden on the seller. The ability to enforce those warranties is therefore of vital importance.

What is the financial ability of the seller to meet those potential obligations? Is the seller going to be around when payments are due? This is particularly relevant if the seller is itself a limited liability company. It is possible that when the time comes to enforce the warranties the company will have been wound up, leaving the warranties with no value.

Therefore, where there is a certain substantial residual financial liability, as highlighted above, it is far safer to deal with it either by a reduction in the price paid or perhaps the deposit of monies to cover this potential liability.

Where the liability is unascertainable but likely, then consideration should be given to a guarantee from a third party for that liability, particularly when the seller is a limited company.

\section{Extent of warranties}

Property warranties are likely to be extensive. In addition to warranties in general terms, specific warranties ought to be included.

It is common to limit the effect of warranties as follows.

- A limit on the period of liability. When agreeing the limit on the period of liability then careful consideration should be given to the specific matters mentioned above. Some of these matters, such as pending rent reviews, pending lease renewals or pending service charge liability, will be short in duration. There will, however, be matters where there could be a substantial period before any liability can be ascertained, such as potential liability for past indemnities.

- Limit on liability. It is common to include a minimum sum below which no claim can be made. If this limit is realistic then there is no particular problem. The wording should be considered so that a series of claims in respect of any particular breach of warranty can be aggregated to avoid the minimum sum limit. If an upper limit is sought by the seller then this must be considered carefully in view of the uncertain liability.

- Requirements for notification of breach of warranty. It is common to include provisions as to notification of potential breach of warranty. These should be considered carefully to ensure that these requirements can be met for any claim. The buyer should also take particular note to ensure that any claim under the 
Purpose of warranties warranties is not avoided by failure to comply with the particular requirements. This is particularly relevant where the buyer enters into negotiations with a third party without notifying the seller of a potential claim for breach of warranty.

- Disclosure letter. The warranties will be limited by the terms of the disclosure letter. The object of the letter is to exclude matters set out in the disclosure letter from the warranties. Particular care should be taken to ensure that the terms of the disclosure letter are not so wide as to exclude the value of the warranties altogether.

\section{Effect of warranties}

The purposes of warranties are to protect the buyer from nondisclosure or to deal with future known or uncertain liabilities. Warranties are not a substitute for a proper due diligence process. They are not designed to protect a lazy or mean buyer who is not prepared to carry out a property due diligence process. It is certainly tempting to minimise the due diligence process to cut costs, but reliance on warranties in substitution for proper due diligence is not a safe option.

\section{SUMMARY}

As can be seen above, the property aspects of a share purchase agreement are just as important as all the other corporate matters. There are matters of particular concern upon which the buyer should focus. The property lawyers should form an active part of the negotiation process and should not be isolated from the transaction. A proper due diligence exercise on property aspects can be expensive and time consuming, but it is something that a prudent buyer should always undertake. 